Lived Religion in the Ancient Mediterranean World 



\section{Lived Religion in the Ancient Mediterranean World}

Approaching Religious Transformations from Archaeology, History and Classics

Edited by

Valentino Gasparini, Maik Patzelt, Rubina Raja, Anna-Katharina Rieger, Jörg Rüpke and Emiliano Rubens Urciuoli in cooperation with Elisabeth Begemann 
Published with support of the European Research Council (ERC).

ISBN 978-3-11-055757-2

e-ISBN (PDF) 978-3-11-055759-6

e-ISBN (EPUB) 978-3-11-055794-7

DOI https://doi.org/10.1515/9783110557596

\section{(cc) BY-NC-ND}

This work is licensed under a Creative Commons Attribution-NonCommercial-NoDerivatives 4.0 International License. For details go to http://creativecommons.org/licenses/by-nc-nd/4.0/.

\section{Library of Congress Control Number: 2019953611}

\section{Bibliographic information published by the Deutsche Nationalbibliothek}

The Deutsche Nationalbibliothek lists this publication in the Deutsche Nationalbibliografie; detailed bibliographic data are available on the Internet at http://dnb.dnb.de.

(C) 2020 Gasparini et al., published by Walter de Gruyter GmbH, Berlin/Boston. This book is published with open access at www.degruyter.com.

Cover image: Sacrificial scene; Roman wall painting.

Edificio B, Murecine/Pompeii, 1st century CE.

(Parco Archeologico di Pompei).

Typesetting: Integra Software Services Pvt. Ltd.

Printing and binding: CPI books $\mathrm{GmbH}$, Leck

www.degruyter.com 